\title{
The Application of Financial Analysis in Business Management
}

\author{
Dan Wang, Fengxia Zhou \\ Beijing Wuzi University, Beijing, China \\ Email: wangdan9080@sohu.com,948148335@qq.com
}

Received 23 May 2016; accepted 10 July 2016; published 13 July 2016

Copyright (C) 2016 by authors and Scientific Research Publishing Inc.

This work is licensed under the Creative Commons Attribution International License (CC BY). http://creativecommons.org/licenses/by/4.0/

(c) (i) Open Access

\begin{abstract}
With the application of financial analysis in business management with the development of economy, enterprises are facing increasingly complex environment. Enterprise modern management is the trend. Financial management is an important part of strengthening the capacity of corporate financial analysis. It has an irreplaceable role to improve their core competitiveness, but this aspect currently in China is still not taken seriously enough. In business management, through the analysis of accurate and comprehensive financial indicators can be more systematic and comprehensive understanding of the enterprise, it can provide a favorable support to make correct and reasonable judgments and decisions, so as to formulate a more comprehensive fit enterprise systems and strategies, a more reasonable and effective, targeted measure for enterprises' sustainable development is important. Its implementation enables businesses to sustainable development.
\end{abstract}

\section{Keywords}

Financial Analysis, Business Management, Impact, Recommendation

\section{The Background of the Study}

Accounting financial analysis is the process and results of carrying out corporate financial activities that are based on the research and evaluation of the company's financial statements and other information, which can reveal the advantages and disadvantages of the business enterprises in the past, analyze financial condition and predict future trends, so that it can be better to help companies plan for the future, optimize investment decisions. Financial analysis is an important part of financial management. It is an important part of financial management in an integral part, and is an important means of financial management. Financial analysis for its many analytical methods can play in economic management in the enterprise evaluation of enterprise financial situation, ex- 
amine the pros and cons of business, and predict business trends important role. Access to business financial information within a certain period of time runs through the financial analysis, and accordingly develops strategic direction or to adjust the development of the business, which is the core of financial management. Financial analysis can help business enterprises to understand the past, evaluate the present situation of enterprises, forecast the future, and provide accurate information for company to make the right decisions and financial basis is an important tool for enterprises to carry out the daily management. The accuracy of financial analysis in business decision-making and the establishment of a scientific financial system promote the standardization of financial management, improve business efficiency and the quality of financial personnel. Other aspects play an important role.

\section{The Present Research Situation of Domestic and Foreign and Review}

\subsection{Foreign Research Status}

Leopold Bernstein [1] thought that the financial analysis is an analytical judgment process, and it is designed to assess companies in the past or financial condition and operating results at this stage, it would be the best predictor of its future financial condition and operating results.

Alexander Wole (1928) [2] in "credit barometer study" and "financial statement ratio analysis" put forward the concept of credit capacity index, he chose the seven financial ratios namely current ratio, equity ratio, the ratio of fixed assets, inventory turnover, accounts receivable turnover, fixed asset turnover and own capital turnover rate, respectively, given the proportion of each index, and then determine the standard rate, the standard rate and the actual rate compared to the relative ratio obtained, and this relative ratio multiplied by the proportion of each index to determine the cumulative score, and the score of the indicators of the overall index, and thus to evaluate the level of corporate credit.

Schouten, the company (1991) put forward the economic value added (EVA) indicator, EVA = total operating profit after tax - the cost of capital, and the enterprise financial statements of the after-tax net profit, operating profit after tax is make necessary adjustment according to the financial statements of the enterprise actual situation, the distortion of financial position data back into real financial performance, however, when the enterprise is not equal to the capital market value and its book value, the calculation results are still error.

Baker driver and others (1997) [3] on the basis of modification to EVA proposed revised economic value added (there), there are $=$ final adjusted operating profit - initial assets market value weighted average cost of capital. Compared with traditional financial analysis methods, EVA and there are considering the actual cost of capital of enterprises, avoid a lot of the management behavior, which combines capital budget, performance evaluation and incentive pay up.

\subsection{Domestic Research Status}

China introduced the "economic benefit evaluation system (trial)", the index system mainly composed of 10 indicators, highlighting the social contribution rate, the rate of accumulation of social, return on capital and capital maintenance and increment ratio and other indicators importance.

Zou jiKang and Qu Zhifeng (2011) [4] in "Chinese Listed Companies Performance Evaluation Index System of" that, under accrual accounting profits as there are many drawbacks performance evaluation index system assessment focus should be on the basis of financial indicators Join cash flow indicators.

Balanced Scorecard as an effective performance management tools, domestic scholars actively explore. Xiao Lijun, the BSC customer dimension expanded into a dimension of social responsibility, and ultimately build a comprehensive performance evaluation system.

Lijun shaw (2012) [5] to expand the balanced scorecard in the customer dimension becomes a dimension of social responsibility, eventually to build a set of comprehensive the performance evaluation index system. Yan Songbing, Ma Jianggong (2012) [6] think that enterprises should correctly understand the cost effectiveness of implementing the balanced scorecard than relationship, can't give up because there is no effect in the short term to build and use the balanced scorecard \# and should focus on long-term benefits.

In contrast, domestic and foreign scholars in their own merits. Theoretical Study abroad started earlier, the analysis system is more mature, but not suited to China's national conditions; theory of our country is a reference to the basis of foreign studies, although the late start, but in recent years some experts, the government be- 
gan a more comprehensive analysis and actively explore.

\section{Significance Analysis of Financial Indicators in Enterprise Management}

Financial analysis index system for the enterprise's creditors, shareholders, managers and staff of its internal financial forecasting and decision to provide protection and support role. Better for rapid development of enterprises play an important role.

\subsection{It Can Provide the Correct Information to Investors and Creditors to Implement Rational Decision}

Through financial analysis, investors can understand the business's profitability and solvency, expected return and risk investment that exist, and then make the right decisions. In recent years, with the diversification of business investors, creditors are not only confined to the National Bank. Financial analysis indicators are an important method of investors and creditors in market economy conditions to obtain the desired information. By business managers to make financial statements on daily financial analysis, to understand their own strengths, its shortcomings found, which can change in time enterprise business strategy.

\subsection{It Can Help Managers to Determine Business Direction}

Enterprise production and management activities has its own laws, to be with the development of production, changes in the volume of business size to make the right business decisions, according to the laws in order to better financial management of enterprises. Through the financial analysis of the business in the past have a clear understanding and summarizing, so that we strengthen the economic activities and the development of understanding of the laws, timely and objective of the financial management activities experience, we found the financial management problems in , objective and reflect the true financial situation of enterprises, and gradually recognized by the law to master and apply the law of financial management activities, give full play to the role of financial management in risk control and management prediction for business decision-makers a comprehensive understanding of financial information, analysing historical performance and forecast future trends and ultimately make a rational economic decision-making to provide strong support.

\subsection{It Can Help Companies to Achieve Their Financial Goals}

For business managers, companies adept at financial management, and maximize enterprise value is important. Through financial analysis, identify their own gaps, and tap the inherent potential, full use of material and human resources, ongoing integration, in order to maximize the corporate value of the target operation, and promote healthy and rapid development. Financial analysis for an enterprise, it is not only the financial activities have been completed in a summary, but it also laid the premise for the financial projections, loop management process in the corporate finance, plays the role of nexus.

\section{The Current Problems of Financial Indicators Analyze}

At present, China's financial analysis system is not perfect, with the continuous development of enterprises, financial analysis is also facing more and more problems and solved.

\subsection{The Financial Statements of Their Own Limitations Exist}

Financial analysis of data derived from the analysis of accounting information, in real life, accounting information distortion, it will affect corporate financial analysis incorrect data, thus affecting the business's policy direction, affecting the development of enterprises. Accounting information distortion mainly the following aspects: the theory of imperfect accounting; accounting management system is not perfect; the interests of drivers; internal control system is imperfect.

\subsection{The Use of Independent Financial Analysis Led to Incomplete Financial Analysis}

Financial analysis often reflect a period or stage of development of enterprises operating conditions, the use of 
independent financial analysis does not come from the analysis of the development situation of the enterprise as a whole, a single index value does not mean that corporate profitability. Usually we need indicators for trend analysis and comparative analysis of the industry. Enterprises are now widespread, "a financial analysis report take the world" status, that no matter who read this report that do not understand the financial information needed to read the object, only provides a model of financial analysis, the report makes readers often get the financial information they really want to know. Affect the quality of financial analysis reports. Or even misleading business owners making an incorrect economic decision affecting the development of enterprises again.

\subsection{The Limitation of Financial Analysis Methods}

There are basic methods of financial analysis ratio analysis, comparative analysis, and trend analysis. Which inevitably need to compare financial indicators, financial indicators usually are quantified, static, and lacking of qualitative analysis, dynamic analysis, and these problems are worth discussing. Emphasis on financial analysis of financial indicators, ignoring the importance of non-financial indicators, and the lack of overall analysis of the enterprise concept, just one isolated indicator analysis. Corporate financial analysis, post hoc analysis of heavy, light but beforehand. In addition, the analysis of the importance of corporate financial awareness is not enough, there is the financial analysis of the quality of personnel is generally not high, the use of computer technology for financial analysis of the degree of popularity.

\section{Countermeasures and Suggestions}

\subsection{Strengthening Financial Management Awareness of Managers at All Levels of the Enterprise, Improving the Ability of Corporate Financial Analysis}

Improve financial analysis capabilities should be from three aspects: to improve the professional quality of corporate financial officers to safeguard the scientific rationality of financial work to ensure accurate financial analysis of sources, reliable; improve enterprise management personnel at all levels and all staff accounting knowledge, financial analysis to ensure fast, smooth and accurate implementation within the enterprise; the formation of financial analysis and efficient team. Financial analysis requires not only a high level of expertise, but also need to have an efficient team to implement specific operations.

\subsection{Improving Constantly and Perfecting the Financial Index System, and Enhancing the Quality of Analysis Process}

Associated increase in financial analysis, financial indicators such as intangible assets, human resources and other financial indicators. Business managers for corporate financial indicators flaws and shortcomings that exist, to strengthen the system of financial indicators improve and perfect. Managers should focus on its own business characteristics, the index system for their own development, not only a financial analysis, but also non-financial analysis. Enterprise product quality, market share, innovation and so on prospects for the development of enterprises have a significant impact. At the same time, increase the content of the notes to financial statements, standardized financial reporting system, an auxiliary of the financial statements is an important way to improve the corporate financial indicators system. Enterprise managers should fully reveal the corporate financial reports and timely disclosure of financial information on enterprise influential.

\subsection{Strengthening Further the Comprehensive Quality of Personal's Financial and Professional Level}

With the reform and development of China's economy, human resources as the company's assets have to be evaluated on the skills of human resource accounting. Enterprise Accounting Financial Analyst at the same time has professional financial knowledge, but also needs to understand and master the relevant expertise to other industries, thereby continuously improve the overall moral quality level of financial personnel, improve the effect of corporate financial analysis to ensure that financial analysts objective fair devoted to financial analysis work, and constantly improve the financial analysis indicators.

The further reform of market economy and improvement of the financial management system of enterprises are becoming increasingly standardized. In the market economy, enterprise business operation is facing numer- 
ous challenges, so that enterprises face the business environment and have undergone great changes, and for the enterprises and business managers, financial management is a very important aspect. Only improving the quality of the corporate financial analysis, it can be better to make the gradual deepening of China's market economy and improve China's modern enterprise systems. Financial analysis as an important part of financial management activities play an increasingly important role in modern companies and only has a rational, scientific, sound financial analysis system in order to more accurately and objectively on the financial situation of enterprises for analysis, enterprise forecasting and decision to make the right judgments. Therefore, the business stakeholders to timely analysis of financial statements do the budget for future operations and management to provide effective basis.

\section{Funding}

This paper is supported by the Beijing Institute of Materials Research Funding (05416049).

\section{References}

[1] Bernstein, L. (1999) Analysis of Financial Statements. McGraw-Hill, Peking University press.

[2] Wole, A. (1928) Research on Credit Barometer. Business Combination, Economic Science Press.

[3] Driver, B., et al. (1997) Economic Value Added (EVA): An Empirical Examination of a New Corporate Performance Measure. Journal of Managerial Issues.

[4] Kang, Z.J. and Qu, Z.F. (2011) Construction of China's Listed Companies Performance Evaluation System. Accounting Monthly, 77-79.

[5] Shaw, L.J. (2012) China's Emerging Strategic Enterprise Performance Evaluation Index System Research. Hubei University of Technology, 13-14, 18-22.

[6] Yan, S.J. and Ma, J.G. (2012) Our Country Enterprise Performance Evaluation Method, the Application of Balanced Scorecard and Strategy. Journal of Accounting Research, 19.

\section{Submit or recommend next manuscript to SCIRP and we will provide best service for you:}

Accepting pre-submission inquiries through Email, Facebook, Linkedin, Twitter, etc

A wide selection of journals (inclusive of 9 subjects, more than 200 journals)

Providing a 24-hour high-quality service

User-friendly online submission system

Fair and swift peer-review system

Efficient typesetting and proofreading procedure

Display of the result of downloads and visits, as well as the number of cited articles

Maximum dissemination of your research work

Submit your manuscript at: http://papersubmission.scirp.org/ 